\title{
Comparison of soil bacterial communities in a natural hardwood forest and coniferous plantations in perhumid subtropical low mountains
}

\author{
Yu-Te Lin', Hsueh-Wen Hu', William B Whitman², David C Coleman³ and Chih-Yu Chiu ${ }^{1 *}$
}

\begin{abstract}
Background: The bacterial community of forest soils is influenced by environmental disturbance and/or meteorological temperature and precipitation. In this study, we investigated three bacterial communities in soils of a natural hardwood forest and two plantations of conifer, Calocedrus formosana and Cryptomeria japonica, in a perhumid, low mountain area. By comparison with our previous studies with similar temperature and/or precipitation, we aimed to elucidate how disturbance influences the bacterial community in forest soils and whether bacterial communities in similar forest types differ under different climate conditions.

Results: Analysis of 165 ribosomal RNA gene clone libraries revealed that Acidobacteria and Proteobacteria were the most abundant phyla in the three forest soil communities, with similar relative abundance of various bacterial groups. However, UniFrac analysis based on phylogenetic information revealed differences of bacterial communities between natural hardwood forest and coniferous plantation soils. The diversities of bacterial communities of the replanted Calocedrus and Cryptomeria forests were higher than that in natural hardwood forest. The bacterial diversity of these three forest soil were all higher than those in the same forest types at other locations with less precipitation or with lower temperature. In addition, the distribution of some of the most abundant operational taxonomic units in the three communities differed from other forest soils, including those related to Acidobacteria, $a-, \beta$ - and $\gamma$-Proteobacteria.
\end{abstract}

Conclusions: Reforestation could increase the bacterial diversity. Therefore, soil bacterial communities could be shaped by the forestry management practices and climate differences in warm and humid conditions.

Keywords: Forest soils; Bacterial community; Bacterial diversity; 165 rRNA genes

\section{Background}

Soil microbes play a key role in organic matter turnover and nutrient cycling (Xu et al. 2008). In forest soils, the activity, diversity and structure of the microbial community are influenced by several environmental factors. For example, tree species diversity is a major factor affecting communities of soil microbes (Curlevski et al. 2010; Liu et al. 2012; Oh et al. 2012). Soil properties variations also are considered to be among the important factors which

\footnotetext{
* Correspondence: bochiu@sinica.edu.tw

${ }^{1}$ Biodiversity Research Center, Academia Sinica, Nankang, Taipei 11529, Taiwan

Full list of author information is available at the end of the article
}

affect the composition of soil bacterial communities. The composition of soil bacterial communities is also related to soil properties, including soil $\mathrm{pH}$ (Lauber et al. 2009), soil C: $\mathrm{N}$ ratio (Högberg et al. 2007) and moisture (Stres et al. 2008). Some evidence also indicated that the community composition responds to regional climate changes in temperature and precipitation (Sowerby et al. 2005; Nielsen et al. 2010). In addition, disturbance of forestry management such as thinning alters soil characteristics (Bolat 2014) and affects the soil microbial community structure and diversity (Chatterjee et al. 2008; Curlevski et al. 2010). The disturbance results in bacterial 
community shifts between natural and disturbed forest soils (Lin et al. 2011a).

Our previous studies showed a greater bacterial diversity of a disturbed hardwood forest soil with annual precipitation $\sim 4,000 \mathrm{~mm}$ in a low mountain region ( 300 $\mathrm{m}$ a.s.l) at Huoshaoliao (Lin et al. 2011b) than that in natural and secondary forest soils at Lienhuachi, with similar elevation but less precipitation (Lin et al. 2011c). The bacterial community at Huoshaoliao is also more diverse than that in a perhumid natural Chamaecyparis forest at Yuanyang Lake forest soils, where is with relatively high elevation $(\sim 1,800 \mathrm{~m}$ a.s.l.) lower mean temperature (Lin et al. 2010). Thus, high bacterial diversity could be due to forest disturbance or temperature and/or precipitation differences.

To elucidate the factor, such as forest disturbance or temperature and/or precipitation that might be important in soil bacterial composition, we investigated natural and disturbed forest soils with similar temperature and precipitation. We examined the diversity and composition of indigenous soil bacterial communities in a low mountain forest located at Wulai in northern Taiwan. This region features a hardwood forest and receives above $4,000 \mathrm{~mm}$ annual precipitation. The site is a subtropical, perhumid montane forest ecosystem with high soil acidity in a monsoonal part of Southeastern Asia. Parts of this region have been replanted by coniferous plantations. We prepared $16 \mathrm{~S}$ rRNA gene clone libraries from these soils to identify soil organisms and to compare soil bacterial communities. The comparison of sequence data includes this study site at Wulai and those from other forests with different climate conditions, including a disturbed hardwood forest in Huoshaoliao (Lin et al. 2011b), a natural Chamaecyparis forest in the Yuanyang Lake forest ecosystem (Lin et al. 2010), and a hardwood forest and a Calocedrus plantation at Lienhuachi (Lin et al. 2011c) (Table 1). The forests in Huoshaoliao and Yuanyang Lake represent a perhumid environment as Wulai, but the mean annual temperature in the Yuanyang Lake forest is lower. The mean annual temperature in Wulai and Lienhuachi forests is similar, but the Lienhuachi ecosystem has less precipitation and is relatively dry during the autumn and winter. The hardwood forest in Wulai and the Chamaecyparis forest in Yuanyang Lake have not experienced human disturbance. The Huoshaoliao forest has undergone timber harvesting for coal-mining construction and for firewood (Lin et al. 2011b) for the heaviest disturbance. Other forest soil communities, including those in Calocedrus and Cryptomeria forests at Wulai and Calocedrus forest at Lienhuachi, have undergone mild disturbance. We used similar datacollection methods at all sites. We hypothesized that 1) disturbance by forest management could result in differences in composition and diversity of bacterial communities between natural hardwood and coniferous forest soils; and 2) a warm and humid climate could result in differences in bacterial communities between similar forest types with different climate conditions. We aimed to elucidate the effects of disturbance and climate conditions on the structure and diversity of communities in subtropical forest soils to help unravel the influence of forest management and climate conditions on forest soil bacterial communities.

\section{Methods}

\section{Site description and soil sampling}

This study was conducted at Wulai, a subtropical low mountain area in northern Taiwan $\left(24^{\circ} 49^{\prime} \mathrm{N}, 118^{\circ} 49^{\prime} \mathrm{E}\right)$ located near the Tonghou Stream, one of the major upstream water resources for Taipei city. This region is humid all year, with mean annual precipitation of $>4,000$ $\mathrm{mm}$. The elevation is $\sim 500 \mathrm{~m}$ a.s.l. and the mean annual temperature $21^{\circ} \mathrm{C}$. The Wulai area is covered mainly by evergreen hardwood forest. Parts of the region have been replanted with coniferous plantations, including Calocedrus formosana and Cryptomeria japonica forests which are around $20 \mathrm{~m}$ height and have planted for more than 40 years. The soils are acidic, and the $\mathrm{pH}$ values of the surface soils range from 3.8 to 4.0 (Table 2). The highest cation exchange capacity (CEC) value was in the hardwood soils, which was associated with relatively high organic $\mathrm{C}$ and clay contents. The low base saturation in these forest soils was resulted from strong leaching of high precipitation.

Table 1 Description of the bacterial 16S rRNA gene clone libraries of forest soils used in the study

\begin{tabular}{|c|c|c|c|c|}
\hline Location & Description of the forest & $\mathrm{MAT}^{\mathrm{a}}$ & Precipitation $(\mathrm{mm})$ & Reference \\
\hline \multirow[t]{3}{*}{ Wulai } & Natural, low mountain hardwood forest in northern Taiwan & 21.0 & $>4,000$ & This study \\
\hline & Low mountain Calocedrus plantation in northern Taiwan & 21.0 & $>4,000$ & This study \\
\hline & Low mountain Cryptomeria plantation in northern Taiwan & 21.0 & $>4,000$ & This study \\
\hline Huoshaoliao & Disturbed, low mountain hardwood forest in northern Taiwan & 21.0 & $>4,000$ & Lin et al. (2011b) \\
\hline \multirow[t]{2}{*}{ Lienhuachi } & Natural, low mountain hardwood forest in central Taiwan & 20.8 & 2,200 & Lin et al. (2011c) \\
\hline & Low mountain Calocedrus plantation in central Taiwan & 20.8 & 2,200 & Lin et al. (2011c) \\
\hline Yuanyang Lake & Natural, middle altitudinal Chamaecyparis forest in northeastern Taiwan & 12.0 & $>4,000$ & Lin et al. (2010) \\
\hline
\end{tabular}




\begin{tabular}{|c|c|c|c|}
\hline Property & Hardwood & Calocedrus & Cryptomeria \\
\hline pH & 4.0 & 3.8 & 3.9 \\
\hline Organic C $\left(\mathrm{g} \mathrm{kg}^{-1}\right)$ & 61.5 & 60.8 & 52.7 \\
\hline Total N ( $\left.\mathrm{g} \mathrm{kg}^{-1}\right)$ & 5.0 & 5.1 & 4.4 \\
\hline $\mathrm{C} / \mathrm{N}$ & 12.3 & 12.0 & 12.0 \\
\hline $\mathrm{CEC}^{\mathrm{a}}\left(\mathrm{cmol}(+) \mathrm{kg}^{-1}\right)$ & 26.0 & 23.2 & 22.5 \\
\hline Base saturation (\%) & 2.4 & 3.2 & 11.6 \\
\hline Sand (\%) & 3.2 & 5.1 & 6.6 \\
\hline Silt (\%) & 43.5 & 45.3 & 45.0 \\
\hline Clay (\%) & 53.3 & 49.7 & 48.4 \\
\hline Soil group & Dystrudept & Dystrudept & Dystrudept \\
\hline
\end{tabular}

${ }^{\mathrm{a}}$ Cation exchange capacity.

Soil samples were collected from hardwood, Calocedrus and Cryptomeria forests in November 2011. Broad-leaved bushes and trees scatter under the hardwood and Calocedrus canopy, with almost no trees under the Cryptomeria canopy because of the deep shade. Three replicate $50 \times 50$ $\mathrm{m}$ plots were selected for each forest type. Each replicate was separated by at least $50 \mathrm{~m}$. The soils were collected with use of a soil auger $8 \mathrm{~cm}$ in diameter and $10 \mathrm{~cm}$ deep. Three subsamples collected in each plot were combined. Visible detritus, such as roots and litter, was manually removed before material was passed through a 2-mm sieve. Soils were then stored at $-20^{\circ} \mathrm{C}$ and extraction of soil community DNA was performed within 2 weeks.

\section{DNA extraction, PCR and 16S rRNA gene clone library construction}

The 16S rRNA gene clone libraries were constructed as described (Lin et al. 2010). DNA of the soil community was extracted by use of the PowerSoil DNA Extraction kit (MoBio Industries, Carlsbad, CA, USA). The bacterial 16S rRNA genes were amplified by PCR with the primer set 27F and 1492R (Lane 1991). After 15 cycles, the PCR products were cloned by use of the TOPO TA cloning kit (Invitrogen, Carlsbad, CA, USA) and the pCR2.1 vector. White colonies on selective Luria-Bertani (LB) agar plates were separated into 96-well blocks containing $1 \mathrm{ml} \mathrm{LB}$ broth plus kanamycin $\left(50 \mu \mathrm{g} \mathrm{ml}^{-1}\right)$ and grown overnight. Sterile glycerol was added to a final concentration of $10 \%$, and an aliquot was transferred to a 96-well sequencing block. Both the sequencing and original culture blocks were stored at $-80^{\circ} \mathrm{C}$.

\section{DNA sequencing and taxonomic assessment}

Bacterial clones were partially sequenced with use of the primer 27F. Sequence analysis involved use of an ABI PRISM Big Dye Terminator cycle sequencing-ready reaction kit and an ABI 3730 Genetic Analyzer (both Applied Biosystems, Foster City, CA, USA). Sequences were analyzed by use of the Mallard and Pintail programs to test for chimeras (Ashelford et al. 2005, 2006). Sequences were taxonomically assigned by use of the naïve Bayesian rRNA classifier, with confidence threshold 80\% (Wang et al. 2007) in the Ribosomal Database Project (http://rdp.cme.msu.edu/index.jsp). The sequences have been deposited into GenBank under accession numbers JN168158-JN168654.

\section{Diversity estimates, library comparison and statistical analyses}

We compared our data with that four soil bacterial communities from a hardwood forest in Huoshaoliao (with climate similar to Wulai but with higher disturbance), hardwood and Calocedrus forests in Lienhuachi (with less precipitation $(2,200 \mathrm{~mm})$ than in Wulai) and a Chamaecyparis forest in Yuanyang Lake forest (with perhumid (precipitation $>4,000 \mathrm{~mm}$ ) and cooler (mean annual temperature $12^{\circ} \mathrm{C}$ ) conditions, as compared with Wulai) described previously (Table 1) (Lin et al. 2010, 2011b, c). The soils in Huoshaoliao and Lienhuach were classified as Dystrudept (U.S. Soil Taxonomy) (Lin et al. 2011b, c), same as soils in Wulai; while soils in Yuanyang Lake forest were Dystrochrept (Lin et al. 2010). The soils in Yuanyang Lake forest were more acidic (pH 3.5) (Lin et al. 2010), and $\mathrm{pH}$ value in Huoshaoliao and Lienhuach is 4.5 and 3.9-4.0, respectively (Lin et al. 2011b, c). Diversity estimates, including ACE, Chao1 estimator, Shannon diversity index, and rarefaction curve were calculated for operational taxonomic units (OTUs) with evolutionary distance (D) of 0.03 (or about 97\% $16 \mathrm{~S}$ rRNA gene sequence similarity) using the DOTUR software package (Schloss and Handelsman 2005). To analyze the distribution of abundant taxa within libraries, groups were constructed by use of DOTUR at a distance of $\leq 0.03$. The taxonomic affiliation of the most abundant OTUs was screened by use of BLAST program in the NCBI Genbank database. These groups were then analyzed by use of the Fisher exact test (Agresti 1992). UniFrac (Lozupone et al. 2006) was used to compare the clone libraries on the basis of the phylogenetic information. The UniFrac Significance test option with 100 permutations was used to determine significant differences between each pair of samples on the basis of phylogenetic information. Jackknife Environment Clusters was used with the weighted algorithm (which considers relative abundance of OTUs) and the normalization step. Relationships between phylogenetic distances of bacterial communities and soil properties were assessed by Mantel tests as implemented in PRIMER v6 (Clarke and Gorley 2006). 


\section{Results}

Phylogenetic groups represented in the clone library

We derived about 50 to 60 clones of $16 \mathrm{~S}$ rRNA genes from each of the three replicate samples collected for the forest soils, and the sequences from replicates of each vegetation type were then combined for further analyses. We obtained 168 clones for the hardwood forest and 168 and 161 clones for Calocedrus and Cryptomeria plantations, respectively. The sequence length determined was about 900 bp. Six clones were chimeras and were removed from the dataset. The remaining clones were classified into 10 phylogenetic groups (Table 3).

In the three soil libraries, Acidobacteria was the most abundant and accounted for more than half of the clones. Proteobacteria comprised about $25 \%$ of all clones and was the second most abundant group. $\alpha$-Proteobacteria was the most abundant class, then $\gamma$-Proteobacteria and $\delta$-Proteobacteria. The remaining phyla, Actinobacteria, Bacteroidetes, Chloroflexi, Firmicutes, Nitrospira, Planctomycetes and Verrucomicrobia all represented less than $7 \%$ of the clones.

Table 4 shows the 20 most abundant genera found in each forest community. The GP1, 2 and 3 were all the most abundant genera in three communities, though the relative abundance of GP3 in hardwood was less than $10 \%$. Other genera all accounted for less than 5\%. In the genera affiliated to $\alpha$-Proteobacteria, including Rhodoplanes and Bradyrhizobium, did not distribute equally among three communities.

Table 3 Phylotypes of clones in 16S rRNA gene libraries

\begin{tabular}{llll}
\hline Phylogenetic group & \multicolumn{3}{l}{ Clone library (\% of clones) } \\
\cline { 2 - 4 } & Hardwood & Calocedrus & Cryptomeria \\
\hline Acidobacteria & $63.7 \mathrm{a}$ & $68.5 \mathrm{a}$ & $59.6 \mathrm{a}$ \\
Actinobacteria & $1.8 \mathrm{a}$ & $0.6 \mathrm{a}$ & $0.0 \mathrm{a}$ \\
Bacteroidetes & $0.0 \mathrm{a}$ & $1.2 \mathrm{a}$ & $1.2 \mathrm{a}$ \\
Chloroflexi & $0.0 \mathrm{~b}$ & $1.2 \mathrm{ab}$ & $3.7 \mathrm{a}$ \\
Firmicutes & $0.0 \mathrm{~b}$ & $1.2 \mathrm{ab}$ & $1.9 \mathrm{ab}$ \\
Nitrospira & $0.6 \mathrm{a}$ & $0.0 \mathrm{a}$ & $0.0 \mathrm{a}$ \\
Planctomycetes & $4.8 \mathrm{a}$ & $0.0 \mathrm{~b}$ & $1.9 \mathrm{ab}$ \\
Proteobacteria & $23.8 \mathrm{a}$ & $25.6 \mathrm{a}$ & $23.0 \mathrm{a}$ \\
a-Proteobacteria & $15.5 \mathrm{a}$ & $17.9 \mathrm{a}$ & $11.8 \mathrm{a}$ \\
B-Proteobacteria & $1.8 \mathrm{a}$ & $0.6 \mathrm{a}$ & $2.5 \mathrm{a}$ \\
Y-Proteobacteria & $4.8 \mathrm{a}$ & $3.0 \mathrm{a}$ & $3.7 \mathrm{a}$ \\
S-Proteobacteria & $1.8 \mathrm{~b}$ & $4.2 \mathrm{ab}$ & $4.3 \mathrm{ab}$ \\
Unclassified Proteobacteria & $0.0 \mathrm{a}$ & $0.0 \mathrm{a}$ & $0.6 \mathrm{a}$ \\
Verrucomicrobia & $5.4 \mathrm{ab}$ & $1.8 \mathrm{~b}$ & $6.2 \mathrm{a}$ \\
Unclassified bacteria & $0.0 \mathrm{a}$ & $0.0 \mathrm{a}$ & $2.5 \mathrm{a}$ \\
Total clone numbers & 168 & 168 & 161 \\
\hline Data with & & $168 \mathrm{~s}$ & \\
\hline
\end{tabular}

Data with the same letter in each row indicates no significant difference by LSD test at $P<0.05$.
The distribution of some bacterial groups in the three Wulai forest soils of hardwood forest and Calocedrus and Cryptomeria plantations differed from those at the other sites previously studied. Within Proteobacteria, $\alpha$-Proteobacteria was the most abundant class in the three Wulai soil communities, but it did not predominate in the hardwood and Chamaecyparis forest soils in Lienhuachi and Yuanyang Lake, where the communities were dominant with $\gamma$ - and $\beta$-Proteobacteria, respectively (Lin et al. 2010, 2011c). In the Calocedrus plantation at Lienhuachi and the hardwood forest at Huoshaoliao, Acidobacteria were abundant in soils but represented less than $50 \%$ of clones (Lin et al. 2011b, c).

\section{Diversity of soil bacterial communities}

Despite the similar relative abundances of various bacterial groups among the three Wulai soil communities, ACE index and Chao1 nonparametric richness estimators revealed greater diversity for the Cryptomeria soil community than hardwood and Calocedrus soil communities (Table 5). Rarefaction analysis also showed that slope of curve was steeper for the Cryptomeria community, which supported above conclusion (Figure 1). In addition, $42 \%$ of clones in Cryptomeria soils were single-member OTUs (singletons). By comparison, 29\% and 30\% of clones in hardwood and Calocedrus soils, respectively, were singletons. As well, the bacterial community was more diverse in the heavily disturbed hardwood in Huoshaoliao forest than Cryptomeria forest in Wulai. The diversity of bacterial communities were similar between hardwood and Calocedrus soils in Wulai and hardwood and Calocedrus soils in Lienhuachi; the Chamaecyparis forest soils in Yuanyang Lake was the least diverse (Figure 1).

\section{Abundant OTUs in soil bacterial communities}

Analyses of community composition revealed that the three soil communities in Wulai significantly differed from each other $(P<0.05)$ and from our previously studied hardwood soils in Huoshaoliao, hardwood and Calocedrus soils in Lienhuachi and Chamaecyparis soils in Yuanyang Lake $(P<0.05)$ (data not shown). On cluster analysis of the clone libraries, the Calocedrus and Cryptomeria communities in Wulai were in the same cluster and differed from that of the hardwood community (Figure 2). Furthermore, the Wulai communities formed a cluster near the Huoshaoliao community, separated from that formed by hardwood and Calocedrus soils in Lienhuachi and the Chamaecyparis forest in Yuanyang Lake.

We found differences in composition by examining of the abundant OTUs with size larger than 10 (Table 6). Because representatives of each OTU were obtained from independent replicates in multiple sampling locations and the representation was similar in the different sample replicates (data not shown), their abundance was 
Table 4 The 20 most abundant genera identified in hardwood forest and Calocedrus and Cryptomeria plantations

\begin{tabular}{|c|c|c|c|c|}
\hline \multirow[t]{2}{*}{ Phylum } & \multirow[t]{2}{*}{ Genus } & \multicolumn{3}{|c|}{ Percentage of clones } \\
\hline & & Hardwood & Calocedrus & Cryptomeria \\
\hline \multirow[t]{3}{*}{ Acidobacteria } & $\mathrm{GP} 1^{\mathrm{a}}$ & 28.0 & 23.2 & 26.7 \\
\hline & GP2 & 22.6 & 27.4 & 17.4 \\
\hline & GP3 & 7.1 & 13.1 & 12.4 \\
\hline Verrucomicrobia & Subdivision3_genera_incertae_sedis & 2.4 & 1.2 & 4.3 \\
\hline Acidobacteria & GP5 & 3.6 & 1.8 & 1.9 \\
\hline \multirow[t]{3}{*}{ Proteobacteria } & Steroidobacter & 3.0 & 1.8 & 0.6 \\
\hline & Rhodoplanes & 3.0 & 0.6 & 1.2 \\
\hline & Bradyrhizobium & 0.6 & 2.4 & 1.9 \\
\hline Verrucomicrobia & Spartobacteria_genera_incertae_sedis & 2.4 & 0.6 & 1.9 \\
\hline Acidobacteria & GP4 & 0.6 & 1.2 & 0.6 \\
\hline Planctomycetes & Planctomyces & 1.2 & 0.0 & 1.2 \\
\hline \multirow[t]{3}{*}{ Proteobacteria } & Pedomicrobium & 0.0 & 1.8 & 0.6 \\
\hline & Burkholderia & 1.2 & 0.0 & 1.2 \\
\hline & Aquicella & 0.0 & 0.6 & 1.2 \\
\hline Acidobacteria & GP6 & 0.0 & 0.6 & 0.6 \\
\hline Actinobacteria & Aciditerrimonas & 0.6 & 0.6 & 0.0 \\
\hline Actinobacteria & Mycobacterium & 1.2 & 0.0 & 0.0 \\
\hline Chloroflexi & Ktedonobacter & 0.0 & 0.6 & 0.6 \\
\hline Planctomycetes & Gemmata & 1.2 & 0.0 & 0.0 \\
\hline Acidobacteria & GP7 & 0.6 & 0.0 & 0.0 \\
\hline
\end{tabular}

${ }^{\mathrm{a} G P}$, group.

not due to PCR or cloning artifacts or to a single unusual sample. Among the three Wulai communities, these clones were mainly representative of Acidobacteria and $\alpha$-Proteobacteria and the distribution differed from that in the other soil communities. The $\beta$-proteobacterial Burkholderia-affiliated OTU was abundant in Chamaecyparis soils in Yuanyang Lake but nearly absent in

Table 5 Diversity indices for the three 16S rRNA gene clone libraries

\begin{tabular}{|c|c|c|c|}
\hline Index & Hardwood & Calocedrus & Cryptomeria \\
\hline $\mathrm{S}^{\mathrm{a}}$ & 87 & 85 & 93 \\
\hline$N^{b}$ & 168 & 168 & 161 \\
\hline ACE & 140 & 165 & 266 \\
\hline Richness $^{c}$ & 0.28 & 0.29 & 0.42 \\
\hline Shannon $^{d}$ & 4.21 & 4.20 & 4.24 \\
\hline Chaol & 138 & 173 & 258 \\
\hline $95 \% \mathrm{COl}^{\mathrm{e}}$ & $112-193$ & $126-271$ & $174-427$ \\
\hline
\end{tabular}

Calculations were based on operational taxonomic units formed at an evolutionary distance of $<0.03$ (or $\sim 97 \%$ similarity).

${ }^{a} \mathrm{~S}$, number of operational taxonomic units observed.

${ }^{\mathrm{b}} \mathrm{N}$, number of sequences.

${ }^{\mathrm{c}}$ Richness $=$ (number of singleton OTUs-1)/logN. The maximum value is

$(\mathrm{N}-1) / \log \mathrm{N}$. The observed/maximum possible value is reported.

${ }^{\mathrm{d}}$ Shannon diversity index $(H)$.

${ }^{\mathrm{e}} 95 \%$ confidence interval for Chao1 estimator.

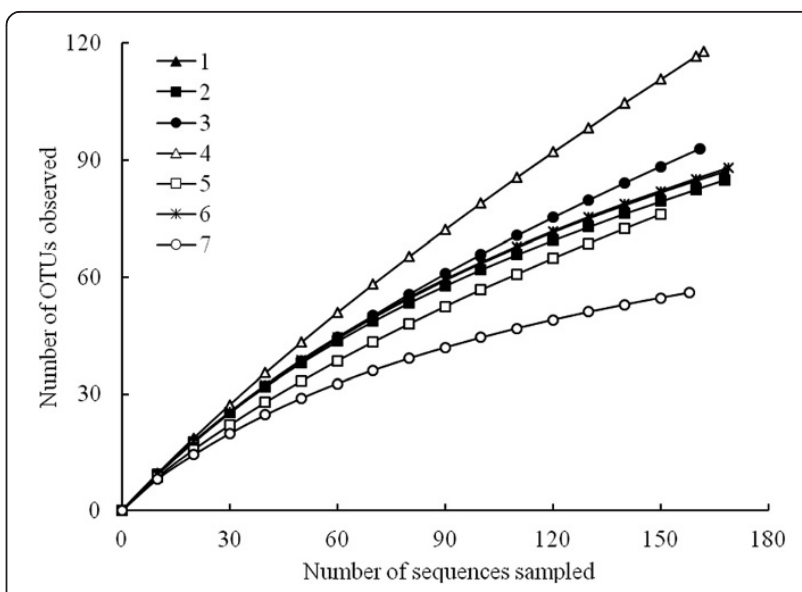

Figure 1 Rarefaction curve analysis for forest soil libraries with OTUs formed at an evolutionary distance $\leq 0.03$ (or about $>97 \%$ similarity). Site notation is as follows: (1) hardwood forest, and (2) Calocedrus and (3) Cryptomeria plantations in Wulai with warm and perhumid conditions; (4) hardwood forest in Huoshaoliao (with climate similar to Wulai but with higher disturbance); (5) hardwood forest and (6) Calocedrus plantation in Lienhuachi (with warmer and less precipitation conditions than in Wulai); (7) Chamaecyparis forest in Yuanyang Lake (with perhumid and cooler conditions, as compared with Wulai). Values for Huoshaoliao, Lienhuachi and Yuanyang Lake forests were calculated from data in Lin et al. (2010, 2011b, c). 


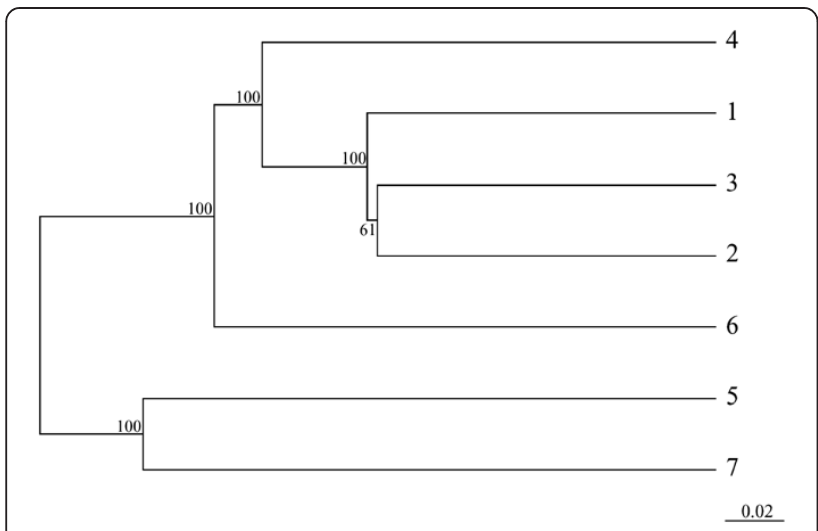

Figure 2 A dendrogram from UniFrac Jackknife environment clusters analysis of $16 \mathrm{~S}$ rRNA gene clone libraries. Analysis involved weighted data. Numbers at nodes indicate the frequency with which nodes were supported by Jackknife analysis. The length of the scale bar indicates a distance of 0.02 . Site notation is as described for Figure 1.

Wulai forest soils. Another abundant OTU closely related to the genus Stenotrophomonas of $\gamma$-Proteobacteria was abundant only in the hardwood forest in Lienhuachi and not detected in Wulai soils. Finally, the most abundant OTU in Wulai soils, acidobacterial GP1-affiliated OTU, with
23 clones, was less abundant in Huoshaoliao, Lienhuachi, and absent in Yuanyang Lake forest soils (Table 5).

\section{Correlation between community composition and soil properties}

Mantel tests of a community assemblage matrix calculated from OTU abundances and pairwise environmental matrices indicated significant correlations $(P<0.05)$ between community and elevation, mean annual temperature and precipitation (Table 7). Other variables, including $\mathrm{pH}$, organic $\mathrm{C}$, total $\mathrm{N}, \mathrm{C}$ : $\mathrm{N}$ ratio and proportion of clay were not significantly correlated with bacterial community structure in these forest soils.

\section{Discussion}

Here, we report on differences in structure among bacterial communities of three Wulai forest soils. In these three soil libraries, Acidobacteria and Proteobacteria were the major phyla, and the relative abundance of various bacterial groups was similar. However, the three libraries significantly differed in microbial composition. Soil microbial communities are different between conifer and broadleaved forests (Ushio et al. 2008), which could release different quality and quantity of litter and root exudates (Sauheitl et al. 2010). Forest management could alter soil

Table 6 Distribution of the most abundant operational taxonomic units (OTUs) in forest soil libraries ${ }^{\mathrm{a}}$

\begin{tabular}{|c|c|c|c|c|c|c|c|c|}
\hline \multirow[t]{2}{*}{ Group $\left(N^{b}\right)$} & \multirow[t]{2}{*}{ Taxonomic affiliation } & \multicolumn{7}{|c|}{ Clone library of each forest $\left(\mathrm{N}^{\mathrm{c}}\right)$} \\
\hline & & 1 & 2 & 3 & $4^{d}$ & $5^{e}$ & $6^{e}$ & $7^{f}$ \\
\hline \multicolumn{9}{|l|}{ Acidobacteria } \\
\hline 27 & Acidobacteria GP19 (EU445214) & 3a & $7 a$ & $7 a$ & 3a & $2 a b$ & $5 a$ & ob \\
\hline 27 & Acidobacteria GP1 (EU680424) & $9 a$ & $4 a b$ & $10 a$ & $3 a$ & $1 \mathrm{bc}$ & Obc & Oc \\
\hline 22 & Acidobacteria GP3 (AY963381) & $6 a b$ & $8 a$ & $3 a b$ & $2 a b c$ & $1 \mathrm{bc}$ & $2 a b c$ & Oc \\
\hline 17 & Acidobacteria GP1 (DQ451448) & $1 \mathrm{abc}$ & $6 a$ & $4 a b$ & Obc & $1 \mathrm{abc}$ & $5 a b$ & Oc \\
\hline 17 & Acidobacteria GP2 (EU881239) & $1 \mathrm{a}$ & 3a & 3a & $1 \mathrm{ab}$ & $3 a$ & $6 a$ & ob \\
\hline 15 & Acidobacteria GP2 (EU680416) & $4 a$ & $1 a b$ & $2 a b$ & $3 a$ & $1 \mathrm{ab}$ & $4 a$ & $\mathrm{Ob}$ \\
\hline 11 & Acidobacteria GP1 (GQ487979) & 2 & 1 & 4 & 4 & 0 & 0 & 0 \\
\hline \multicolumn{9}{|c|}{ a-Proteobacteria } \\
\hline 30 & Stenotrophomonas (FJ894817) & $0 \mathrm{~b}$ & $\mathrm{Ob}$ & $\mathrm{Ob}$ & $0 \mathrm{~b}$ & $28 a$ & $2 b$ & ob \\
\hline 25 & Rhodoplanes (EU881284) & 4 & 3 & 3 & 6 & 1 & 3 & 5 \\
\hline 16 & Bradyrhizobium (FJ592549) & 1 & 4 & 4 & 2 & 0 & 1 & 4 \\
\hline 16 & Steroidobacter (JF833908) & $2 a b$ & $3 a b$ & Oab & $3 a b$ & $4 a$ & $3 a b$ & $1 \mathrm{~b}$ \\
\hline \multicolumn{9}{|c|}{$\beta$-Proteobacteria } \\
\hline 28 & Burkholderia (AY949190) & $1 b$ & $a b$ & $\mathrm{Ob}$ & ob & $2 b$ & ob & $25 a$ \\
\hline
\end{tabular}

Site notation is as follows: (1) hardwood forest, and (2) Calocedrus and (3) Cryptomeria plantations in Wulai; (4) hardwood forest in Huoshaoliao; (5) hardwood forest and (6) Calocedrus plantation in Lienhuachi; (7) Chamaecyparis forest in Yuanyang Lake.

${ }^{a}$ OTUs formed at an evolutionary distance $\leq 0.03$ (or about $>97 \%$ similarity). Data with the same letter in each row indicates no significant difference by LSD test at $P<0.05$.

${ }^{\mathrm{b}}$ Total number of clones in an OTU.

'Number of clones in each library.

${ }^{\mathrm{d}}$ Data from Lin et al. (2011b).

eData from Lin et al. (2011c).

fData from Lin et al. (2010).

${ }^{9} \mathrm{GP}$, group. 
Table 7 Correlation of bacterial communities with environmental properties ${ }^{\mathrm{a}}$

\begin{tabular}{ll}
\hline Soil properties & Spearman rank correlation \\
\hline Elevation & $\mathbf{0 . 6 2 1}$ \\
Mean annual temperature & $\mathbf{0 . 6 0 4}$ \\
Precipitation & $\mathbf{0 . 6 9 8}$ \\
$\mathrm{pH}$ & 0.285 \\
Organic C & 0.414 \\
Total N & 0.407 \\
C:N ratio & 0.108 \\
Clay & 0.418 \\
\hline
\end{tabular}

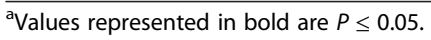

properties, microclimatic conditions, microbial biomass (Bolat 2014), and thereby affect the functional diversity of soil microbial communities (Gömöryová et al. 2009). The composition of the soil microbial community could be influenced by the soil $\mathrm{C} / \mathrm{N}$ ratio and the response of trees to this ratio (Högberg et al. 2007). Lucas-Borja et al. (2012) indicated that tree species affect the biomass of the soil microbial community and its structure, which could explain the different bacterial clusters we found between hardwood and Calocedrus and Cryptomeria soils in Wulai. In addition, interactions between trees and understory plants in the Calocedrus plantation could also structure a different community from that in Cryptomeria soils (Mitchell et al. 2012). Differences in climate conditions could also structure the composition of the bacterial community. A landscape-scale study in Scotland showed that the composition of soil bacterial community was related to variation in precipitation (Nielsen et al. 2010). Precipitation could affect bacterial communities indirectly by changing the soil moisture, which may have resulted in composition differences between Wulai and Lienhuachi forest communities (Guenet et al. 2012). Soil pH is a well-known factor to predict bacterial diversity and structure (Tripathi et al. 2012). Some other soil properties, including organic C, total $\mathrm{N}$ and $\mathrm{C} / \mathrm{N}$ ratio, also affect the relative abundance of copiotrophic/oligotrophic microbes (Nemergut et al. 2010), though they are all not significantly correlated with soil communities in this study. Environmental factors caused by climate condition differences, as well as management, could have important effects on bacterial communities.

Rarefaction analysis revealed all that three Wulai forest soil communities were more diverse than natural Chamaecyparis soil communities in Yuanyang Lake forest. The disturbance of forest soils could increase the diversity of microbial communities (Jangid et al. 2010; Lin et al. 2011a) and result in increased bacterial diversity in the Cryptomeria soils in Wulai. The most disturbed soil bacterial community of Huoshaoliao forest with similar climate conditions to that for Wulai communities, showed a highly diverse bacterial community.
Besides disturbance, temperature might cause the low diversity in the Chamaecyparis forest community. Temperature and moisture condition changes have been linked to changes in microbial community composition (Lipson 2007). The relatively high altitude of the Chamaecyparis forest in Yuanyang Lake implies increased environmental harshness, including lower annual temperature, which in turn affects the composition and diversity of the soil bacterial community (Lipson 2007). The bacterial diversity among different forest types, including hardwood and Calocedrus forests in Wulai and Lienhuachi, was similar, despite different precipitation conditions. Brockett et al. (2012) found soil moisture to be the major factor influencing microbial community structure across seven biogeoclimatic zones in western Canada. Data for more forests with different degree of disturbance and/or precipitation are needed to investigate whether disturbance and precipitation are a major factor influencing bacterial community diversity.

The phylum Acidobacteria is distributed widely in various soil environments (Zimmermann et al. 2005; Araujo et al. 2012; Meng et al. 2013), and its abundance is significantly correlated with soil pH (Lauber et al. 2009). The forests we compared all possessed low soil $\mathrm{pH}$ values, and Acidobacteria was also abundant in most of the microbial communities. However, its relative abundance was lower in the hardwood forest soils in Lienhuachi and Chamaecyparis soils in Yuanyang Lake than in other communities. In a continental scale study, Acidobacteria accounted for more than $60 \%$ of the microbial community (Lauber et al. 2009). The species are also known to be cultured in media with low pH (Sait et al. 2006). Including data of soil bacterial communities in different forest type would be worthwhile to elucidate which factors influence the abundance of Acidobacteria in these two communities with low soil $\mathrm{pH}$. A recent study of the whole-genome sequences of three Acidobacteria strains revealed that they are versatile heterotrophs and have slow metabolic rates under low nutrient conditions (Ward et al. 2009). In this study, however, the abundant genera of this phylum, including GP1, 2, and 3, were not closely related to the described strains. Thus, determining the functional and physical roles in the ecosystems is difficult. In light of the abundance of the phylum in different forest soil communities, further examination of clones in pure cultures for physiological characteristics should have high priority.

Proteobacteria are abundant in different forest soil communities (Janssen 2006). The class $\alpha$-Proteobacteria represented most of the proteobacterial clones in our three Wulai communities. The clones related to the order Rhodoplanes and Bradyrhizobium were found in these three communities. They include species involved in $\mathrm{N}$ fixation, organic matter decomposition, and plant growth promotion (Zhang and $\mathrm{Xu}$ 2008; Yarwood et al. 2009). Their 
physiological properties suggest the potential role of the bacterial community for $\mathrm{N}$ budget and nutrient cycles in these ecosystems.

\section{Conclusion}

In conclusion, plantation changes bacterial composition between natural hardwood forest and coniferous plantations. The climate differences in warm and humid conditions could determine difference of community structure, as well as disturbance of forestry management practices. The forest management could also increase the bacterial diversity. These findings could help improve our understanding of variations in soil bacterial communities between natural and disturbed forests under different climate conditions. Also, related information could be applied to conservation efforts in the fields of forest management and climate change.

\section{Competing interests}

The authors declare that they have no competing interests.

\section{Authors' contributions}

YTL designed and conducted the research. HWH conducted some laboratory tests. WBW and DCC helped in analyzing and interpreting data. YTL and CYC wrote the manuscript with inputs from other authors. All authors read and approved the final manuscript.

\section{Acknowledgements}

This work was supported in part by the National Science Council, Taiwan (NSC101-2621-B-001-002-MY3).

\section{Author details}

${ }^{1}$ Biodiversity Research Center, Academia Sinica, Nankang, Taipei 11529, Taiwan. ${ }^{2}$ Department of Microbiology, University of Georgia, Athens, GA, 30602-2605, USA. ${ }^{3}$ Odum School of Ecology, University of Georgia, Athens, GA, 30602-2602, USA.

Received: 17 February 2014 Revised: 14 April 2014

Accepted: 18 May 2014

\section{References}

Agresti A (1992) A survey of exact inference for contingency tables. Statist Sci 7:131-153

Araujo JF, de Castro AP, Costa MMC, Togawa RC, Pappas GJ Jr, Quirino BF, Bustamante MMC, Williamson L, Handelsman J, Krüger RH (2012) Characterization of soil bacterial assemblies in Brazilian savanna-like vegetation reveals Acidobacteria dominance. Microb Ecol 64:760-770

Ashelford KE, Chuzhanova NA, Fry JC, Jones AJ, Weightman AJ (2005) At least 1 in $2016 \mathrm{~S}$ rRNA sequence records currently held in public repositories is estimated to contain substantial anomalies. Appl Environ Microbiol 71:7724-7736

Ashelford KE, Chuzhanova NA, Fry JC, Jones AJ, Weightman AJ (2006) New screening software shows that most recent large 165 rRNA gene clone libraries contain chimeras. Appl Environ Microbiol 72:5734-5741

Bolat I (2014) The effects of thinning on microbial biomass C, N and basal respiration in black pine forest soils in Mudurnu, Turkey. Eur J Forest Res 133:131-139

Brockett BFT, Prescott CE, Grayston SJ (2012) Soil moisture is the major factor influencing microbial community structure and enzyme activities across seven biogeoclimatic zones in western Canada. Soil Biol Biochem 44:9-20

Chatterjee A, Vance GF, Pendall E, Stahl PD (2008) Timber harvesting alters soil carbon mineralization and microbial community structure in coniferous forests. Soil Biol Biochem 40:1901-1907

Clarke KR, Gorley RN (2006) Primer v6: user manual/tutorials. Primer-E Ltd, Plymouth
Curlevski NJA, Xu Z, Anderson IC, Cairney JWG (2010) Converting Australian tropical rainforest to native Araucariaceae plantations alters soil fungal communities. Soil Biol Biochem 42:14-20

Gömöryová E, Hrivnák R, Janišová M, Ujházy K, Gömöry D (2009) Changes of the functional diversity of soil microbial community during the colonization of abandoned grassland by a forest. Appl Soil Ecol 43:191-199

Guenet B, Lenhart K, Leloup J, Giusti-Miller S, Pouteau V, Mora P, Nunan N, Abbadie $L$ (2012) The impact of long-term $\mathrm{CO}_{2}$ enrichment and moisture levels on soil microbial community structure and enzyme activities. Geoderma 170:331-336

Högberg M, Högberg P, Myrold D (2007) Is microbial community composition in boreal forest soils determined by $\mathrm{pH}, \mathrm{C}$-to- $\mathrm{N}$ ratio, the trees, or all three? Oecologia 150:590-601

Jangid K, Williams MA, Franzluebbers AJ, Blair JM, Coleman DC, Whitman WB (2010) Development of soil microbial communities during tallgrass prairie restoration. Soil Biol Biochem 42:302-312

Janssen PH (2006) Identifying the dominant soil bacterial taxa in libraries of $16 \mathrm{~S}$ rRNA and 16S rRNA genes. Appl Environ Microbiol 72:1719-1728

Lane DJ (1991) 16S/23S rRNA sequencing. In: Stackbrandt E, Goodfellow M (eds) Nucleic acid techniques in bacterial systematics. Wiley, New York, pp 115-175

Lauber CL, Hamady M, Knight R, Fierer N (2009) Pyrosequencing-based assessment of soil $\mathrm{pH}$ as a predictor of soil bacterial community structure as the continental scale. Appl Environ Microbiol 75:5111-5120

Lin YT, Huang YJ, Tang SL, Whitman WB, Coleman DC, Chiu CY (2010) Bacterial community diversity in undisturbed perhumid montane forest soils in Taiwan. Microb Ecol 59:369-378

Lin YT, Jangid K, Whitman WB, Coleman DC, Chiu CY (2011a) Soil bacterial communities in native and regenerated perhumid montane forests. Appl Soil Ecol 47:111-118

Lin YT, Whitman WB, Coleman DC, Chiu CY (2011b) Molecular characterization of soil bacterial community in a perhumid, low mountain forest. Microbes Environ 26:325-331

Lin YT, Jangid K, Whitman WB, Coleman DC, Chiu CY (2011c) Change in bacterial community structure in response to disturbance of natural hardwood and secondary coniferous forest soils in central Taiwan. Microb Ecol 61:429-437

Lipson DA (2007) Relationships between temperature responses and bacterial community structure along seasonal and altitudinal gradients. FEMS Microbiol Ecol 59:418-427

Liu D, Fang S, Tian Y, Dun X (2012) Variation in rhizosphere soil microbial index of tree species on seasonal flooding land: An in situ rhizobox approach. Appl Soil Ecol 59:1-11

Lozupone C, Hamady M, Knight R (2006) UniFrac - an online tool for comparing microbial community diversity in a phylogenetic context. BMC Bioinforma 7:371

Lucas-Borja ME, Candel D, Jindo K, Moreno JL, Andrs M, Bastida F (2012) Soil microbial community structure and activity in monospecific and mixed forest stands, under Mediterranean humid conditions. Plant Soil 354:359-370

Meng H, Li K, Nie M, Wan JR, Quan ZX, Fang CM, Chen JK, Gu JD, Li B (2013) Responses of bacterial and fungal communities to an elevation gradient in a subtropical montane forest of China. Appl Microbiol Biotechnol 97:2219-2230

Mitchell RJ, Keith AM, Potts JM, Ross J, Reid E, Dawson LA (2012) Overstory and understory vegetation interact to alter soil community composition and activity. Plant Soil 352:65-84

Nemergut DR, Cleveland CC, Wieder WR, Washenberger CL, Townsend AR (2010) Plot-scale manipulations of organic matter inputs to soils correlate with shifts in microbial community composition in a lowland tropical rain forest. Soil Biol Biochem 42:2153-2160

Nielsen UN, Osler GHR, Campbell CD, Burslem DFRP, der Wal v (2010) The influence of vegetation type, soil properties and precipitation on the composition of soil mite and microbial communities at the landscape scale. $J$ Biogeogr 37:1317-1328

Oh YM, Kim M, Lee-Cruz L, Lai-Hoe A, Go R, Ainuddin N, Rahim AR, Shukor N, Adams JM (2012) Distinctive bacterial communities in the rhizoplane of four tropical tree species. Microb Ecol 64:1018-1027

Sait M, Davis KER, Janssen PH (2006) Effect of pH on isolation and distribution of members of subdivision 1 of the phylum Acidobacteria occurring in soil. Appl Environ Microbiol 72:1852-1857

Sauheitl L, Glaser B, Dippold M, Leiber K, Weigelt A (2010) Amino acid fingerprint of a grassland soil reflects changes in plant species richness. Plant Soil 334:353-363

Schloss PD, Handelsman J (2005) Introducing DOTUR, a computer program for defining operational taxonomic units and estimating species richness. Appl Environ Microbiol 71:1501-1506 
Sowerby A, Emmett B, Beier C, Tietema A, Peñuelas J, Estiarte M, Van Meeteren MJM, Hughes S, Freeman C (2005) Microbial community changes in heathland soil communities along a geographical gradient: interaction with climate change manipulations. Soil Biol Biochem 37:1805-1813

Stres B, Danevčič T, Pal L, Fuka MM, Resman L, Leskovec S, Hacin J, Stopar D, Mahne I, Mandic-Mulec I (2008) Influence of temperature and soil water content on bacterial, archaeal and denitrifying microbial communities in drained fen grassland soil microcosms. FEMS Microbiol Ecol 66:110-122

Tripathi BM, Kim M, Singh D, Lee-Cruz L, Lai-Hoe A, Ainuddin AN, Go R, Rahim RA, Husni MHA, Chun J, Adams JM (2012) Tropical soil bacterial communities in Malaysia: pH dominates in the equatorial tropics too. Microb Ecol 64:474-484

Ushio M, Wagai R, Balser TC, Kitayama K (2008) Variations in the soil microbial community composition of a tropical montane forest ecosystem: does tree species matter? Soil Biol Biochem 40:2699-2702

Wang Q, Garrity GM, Tiedje JM, Cole JR (2007) Naïve Bayesian classifier for rapid assignment of rRNA sequences into the new bacterial taxonomy Appl Environ Microbiol 73:5261-5267

Ward NL, Challacombe JF, Janssen PH, Henrissat B, Coutinho PM, Wu M, Xie G, Haft DH, Sait M, Badger J, Barabote RD, Bradley B, Brettin TS, Brinkac LM, Bruce D, Creasy T, Daugherty SC, Davidsen TM, DeBoy RT, Detter JC, Dodson RJ, Durkin AS, Ganapathy A, Gwinn-Giglio M, Han CS, Khouri H, Kiss H, Kothari SP, Madupu R, Nelson KE et al (2009) Three genomes from the phylum Acidobacteria provide insight into the lifestyles of these microorganisms in soils. Appl Environ Microbiol 75:2046-2056

Xu ZH, Ward S, Chen CR, Blumfield T, Prasolva N, Liu JX (2008) Soil carbon and nutrient pools, microbial properties and gross nitrogen transformations in adjacent natural forest and hoop pine plantations of subtropical Australia. J Soils Sediments 8:99-105

Yarwood SA, Myrold DD, Högberg MN (2009) Termination of below-ground C allocation by tree alters soil fungal and bacterial communities in a boreal forest. FEMS Microbiol Ecol 70:151-162

Zhang L, Xu Z (2008) Assessing bacterial diversity in soil. J Soils Sediments 8:379-388

Zimmermann J, Gonzalez JM, Saiz-Jimenez C, Ludwig W (2005) Detection and phylogenetic relationships of highly diverse uncultured acidobacterial communities in Altamira Cave using $23 \mathrm{~S}$ rRNA sequence analyses. Geomicrobiol J 22:379-388

doi:10.1186/s40529-014-0050-x

Cite this article as: Lin et al:: Comparison of soil bacterial communities in a natural hardwood forest and coniferous plantations in perhumid subtropical low mountains. Botanical Studies 2014 55:50.

\section{Submit your manuscript to a SpringerOpen ${ }^{\circ}$ journal and benefit from:}

- Convenient online submission

- Rigorous peer review

- Immediate publication on acceptance

- Open access: articles freely available online

- High visibility within the field

- Retaining the copyright to your article

Submit your next manuscript at $\gg$ springeropen.com 